J O U R N A L O F French and Francophone Philosophy
RE V UE DE LA

philosophie française et de langue française

\title{
Pedagogy of the Written Image
}

Jonathan Lahey Dronsfield

Journal of French and Francophone Philosophy - Revue de la philosophie française et de langue française, Vol XVIII, No 2 (2010) pp 87- 105

\author{
Vol XVIII, No 2 (2010) \\ ISSN 1936-6280 (print) \\ ISSN 2155-1162 (online) \\ DOI $10.5195 /$ jffp. 2010.214 \\ http://www.jffp.org
}

\section{(cc) EY-NC-ND}

This work is licensed under a Creative Commons Attribution-Noncommercial-No Derivative Works 3.0 United States License.

\section{ULIS D-Sunt}

This journal is published by the University Library System of the University of Pittsburgh as part of its D-Scribe Digital Publishing Program, and is co-sponsored by the University of Pittsburgh Press 


\title{
Pedagogy of the Written Image
}

\author{
Jonathan Lahey Dronsfield \\ University of Reading
}

Readings are just fantastic! When you get right down to it, the most fantastic thing you could film is people reading. I don't see why no one's done it. Film someone who's simply reading...

- Jean Luc-Godard ${ }^{1}$

1.

Text, it is Jean-Luc Godard's "ennemi royal, principal". ${ }^{2}$ Text, it is on the side of death, "les images c'est la vie et les textes, c'est la mort". ${ }^{3}$ Twenty years later and the war is not over: "Une image est paisible. Une image de la Vierge avec son petit enfant sur son âne n'amène pas la guerre, c'est son interprétation par un texte qui amènera la guerre et qui fera que les soldats de Luther iront déchirer les toiles de Raphaël." ${ }^{\prime 4}$ Godard's story is not just of the history of cinema, it is one in which text has won out to the extent that TV and the computer too make of the image something subservient to text. "Since Gutenberg" the text has triumphed in this way. "There was a long struggle, marriage or liaison between painting and text. Then the text carried the day. Film is the last art in the pictorial tradition... Take away the text and you'll see what's left. In TV nothing is left." ${ }^{5}$ It is obvious from these lines of demarcation, lines which divide the art of the image from what would declare war on its most sacred icons and defeat its technologies, a conflict in which there is just the one aggressor, a division which makes of the relation between image and text nothing less than a matter of life and death, that for Godard text is indeed the enemy.

Except that the matter is not as simple as this pitch would pretend. Not just because for a cinéaste with a love for the cinema writing can be a way of making films, "To us, writing about films or going to the cinema was the same as making movies". Not just because text in the hands of the right critic is a declaration of love for the cinema, "To love someone blindly is to love 
someone unquestioningly. We in the nouvelle vague loved the cinema before we had actually seen it." ${ }^{\prime 6}$ Not just because it is only when words are taken as orders, unthinkingly, like a knife used malevolently, only then is text lifethreatening. ${ }^{7}$ And not just because the history of cinema cannot be told without text, the history of cinema being a history of its defeat by text or its resistance to it. Rather, it is because in order to do film it is impossible to be against death, in order to do film it is necessary to risk death; or in other words, to make a film it is necessary to make of death a formidable power of life, and that means making text the life of a film. ${ }^{8}$ Godard's Histoire(s) $d u$ cinéma is a culminative work in this respect. More than just a meditation on the struggle between life and death, it is a work which makes of text a power of life by being as much a book as it is a film. Not just in its format (book and videocassette) or in how the film is structured (chapters), but more importantly still in how 'the book' is itself a persona in the film. But it is a persona without any interiority, it is a persona at the level of 'it speaks'. Books feature throughout the film's chapters, they speak, there is the sound of them being written. Both the film and the book Histoire(s) du cinéma are expressions of the "fraternité ou de l'égalité" of image to text, and Godard admits that the book is perhaps more successful in this respect than the film. ${ }^{9}$ Histoire(s) is, then, as much an attempt to re-write the history of cinema as it is to retrieve it from the dictatorship of the script.

In Film Socialisme, Godard's most recent film (2010), no less than thirty four authors are credited as textual source. There is a scene in the film where Alain Badiou lectures on Husserl to an empty lecture theatre on board a cruise ship. Godard did not construct this scene, in the sense that he did not arrange to have no-one turn up. But the scene could not have served better to show what it is to read from a text. Godard wanted to quote from Husserl's Origin of Geometry and he invited Badiou to develop something of his own from that quotation (Badiou is not one of the authors credited as textual source), but no-one turned up to listen. To quote from a text is to speak it not to someone other but to oneself, and in doing so to hear oneself as someone other. Badiou remarked on entering the empty auditorium "Enfin, je peux parler devant personne." ${ }^{10}$ But what he might have said is that finally he gets to speak in front of the book. Books have a constitutive role in Godard's film practice, they have always appeared in his films. And those books are often voiced over by a reflection on what it is to read, where the questions posed about reading are themselves quotations from books, and in particular the writings of philosophers, for instance Heidegger and Wittgenstein. ${ }^{11}$ But Godard professes not to know how to read such books, "Lire des livres «techniques» de philosophie," he says, “j'en suis incapable". ${ }^{12}$ He has been saying so from the start, see his remarks on Foucault (the "Reverend Doctor Foucault") in the interview from which comes our epigram. ${ }^{13}$ Mindful of Robert Bresson's dictum, that "Ideas gathered from reading will always be bookish ideas", Godard approaches the book as if it were a persona, a persona lacking interiority but not a 
certain legibility, the impersonal 'it speaks'. ${ }^{14}$ Rather than read the book, he maintains that he hears what he sees there: "Mais lorsque vous, ou bien d'autres, citez un auteur ou parlez d'un livre vous l'avez vraiment lu, de ma part j'entends un son, je pense qu'il doit aller là, il y a un mélange." ${ }^{15}$ And by mélange he means the way images of text and sounds of text are placed with images in which they would not ordinarily be found: "Ça ne me gêne pas d'utiliser une phrase de Heidegger, alors que normalement on ne le mettrait pas dans un roman policier". ${ }^{16}$ Thus if Godard quotes from a text by Heidegger it is not because he knows how to read a text by Heidegger, for he is "incapable of reading Heidegger", it is because the text by Heidegger, the word of Heidegger spoken in the image with which it is mixed, plays a part in making visible what can be seen by making itself seen. ${ }^{17}$

If Godard quotes a text by Heidegger it is because the text is necessary for the seen to become visible. He reads aloud from books in order that what the film shows become visible. This is the sense in which a phrase from Heidegger is needed, "Pas pour voir, mais pour faire voir". It is as if the seen is not able to communicate what it is without being made visible by words. "Pour faire voir ce qu'on a vu. If faut des mots pour transmettre." ${ }^{18}$ In order that what there is become visible, text is necessary. It is not that text is subsidiary; on the contrary, there would be no need to resist it were that the case. It is that there is no visibility without text. This is the ground of Godard's resistance to it, because it invites the thought that image is invisible without text, or at least dependent on text for its visibility. But we must be careful not to make of dependency a one-way relation, or the power of text something opposed to that of the image. If we maintain that the image would not be visible without text, we insist at the same time that there is no text legible without the image. To suppose that text can put image to the death arises from the mistaken presupposition that one can be purified of the other. Godard fights the power of text, and testifies to that power in doing so. But what he also does is reveal the necessary complicity between text and image, he negates the hierarchy between them, he demonstrates their co-dependency their co-originality, he shows that you cannot have one without the other. If Godard does not reject death it is because he sees it as repetition, he sees it not as end but as and; text as the death to be risked is the possibility of resistance. Text is what Godard resists and that to which he turns in resisting it.

2.

What is philosophically important about text in Godard's films is the way in which he elevates it to the status of image. We shall name such an image the written image. It is an image which takes not just the form of the book appearing in the frame but the inscription of text within and across the frame - images of text handwritten, typewritten, electronically generated, found, thrown. We will argue that it is with the written image that Godard confers a new visibility on film, and that such visibility is as much a matter 
of the legibility of the image as it is of what is to be seen. It is this legibility that Gilles Deleuze calls Godard's pedagogy of the image. Deleuze takes his lead from Godard's militant conception of the pedagogical function of the film frame: "l'écran est simplement un tableau noir ou un mur d'école qui offre l'analyse concrète d'une situation concrète", 19 to make a "concrete analysis' of a 'concrete situation' being the thirteenth edict of 'What is to be done', ${ }^{20}$ the 'Maoist' manifesto accompanying the 1970 film British Sounds. Deleuze draws on this sloganising of the frame when stating in the first few pages of Cinéma I that "le cadre nous apprendre ainsi que l'image ne se donne pas seulement à voir. Elle est lisible autant que visible." ${ }^{21}$ If the image in Godard can function to record sound and image information in such a way as to make it legible as well as visible it is because for Deleuze the Godardian frame is essentially empty, an opaque surface, white or black, what elsewhere he calls a 'plan fixe'. ${ }^{22}$ Or in other words, the screen is a blackboard. There are numerous examples of the blackboard featuring as the frame for the inscription of text in Godard's films, especially those from the first half of his career leading up to the beginning of the making of Histoire(s) du cinéma in 1988, from the would-be revolutionaries of La Chinoise learning how to speak the text of Mao's Little Red Book, through the 'Leçons de choses' of Six fois deux, to the biblical opacity of Sauve qui peut (la vie). But Deleuze's point is that the screen as such is for Godard a blackboard. It is not that Godard's films show the blackboard as they would an object, it is that the film screen is a blackboard, in the sense that it is a surface on which everything can be shown equally. Serge Daney, one of Deleuze's interlocutors on cinema, argues that Godard's screen is an empty blackboard because the sine qua non of Godardian pedagogy is to take the text at its word, the statement as already given, in order then to oppose another word, another statement. ${ }^{23}$ Thus the screen must be empty in order that it become the site of a struggle, the place where opposing discourses can co-exist in such a way that Godard's stance toward the good discourse, for instance Maoist doctrine, be undecidable, what Daney calls "the great unknown" in Godard's pedagogy. But we must pause in the face of the claim that Godard's method is one of setting up oppositions or of opposing one thing to another, precisely because of the relation between disjoining and joining and the play between image and text exemplified by the written image in his films.

Deleuze is in agreement with Daney, the screen is essentially empty, it is a fixed background, and this is what is so new about Godard. But it is what Godard's pedagogy aims for according to Deleuze that is of interest: belief in the world, belief not in another world or a transformed world or an idealised world but belief in this world. But by 'this world' Deleuze means a world "en deça ou au-delà des mots". ${ }^{24}$ As if Godard wishes to restore belief in a world "before or beyond words", as if a world "before or beyond words" is truly the one in which we live - if only we could see it, where seeing would be believing. Then this world is not of its time, because its 
ways of seeing are not present unto itself, this world's time is not its own. What is it that leads Deleuze to dream of such a world, a world 'before and beyond words', a world which is no more possible, or no more a world, than an empty film frame? He is determined to enlist Godard in the aesthetic project he inherits from Artaud, to separate word from image, a project to return and restore the word to its proper place, the body. It is the other side of the call in Différence et répétition to rid thinking of the image in the name of Artaud's 'terrible revelation' of an "image without thought", 25 something Deleuze finally gives up on to the extent that in the late Qu'est-ce que la philosophie? great philosophers are measured by their ability to produce new images of thought. ${ }^{26}$ If the screen is opaque it is not because it is empty, it is not because it presents a neutral ground on which to stage an opposition in which Godard does not take sides yet from which emerges the possibility of a world 'free from words', a world restored to its original unity 'before the word', it is because an opaque screen arrests the image, stops it in order for it to be looked at again or seen for the first time, and it is seen again as if for the first time not because it has been resurrected from subservience to text, but because it is brought face-to-face with text, it is given to be encountered by text, both text from without and text within the image, the image is stopped in order that its text be seen, that it be brought to encounter its own text, and that its text be made legible.

It is a defining characteristic of modern cinema, for Deleuze, that the image is more 'legible' ['lisible'] than visible. It is this that makes possible "toute une pédagogie de l'image". The legibility is primarily given by new relations between the aural and the optical, sound and image, in which word plays a subsidiary role. ${ }^{27}$ In this 'pedagogy of perception' (Deleuze borrows the term from Daney) it is the dissymmetry and disjunction between the aural and visual "qui allaient donner à l'oeil un pouvoir de lire l'image". ${ }^{28}$ But the opposition between the aural and the visual, the ear and the eye, locates word on one side, that of sound, at the expense of word as image. In the last section of the final chapter of the second cinema volume, L'image temps, Deleuze develops most fully his understanding of pedagogy in modern cinema, with Godard its most important exponent. ${ }^{29}$ Deleuze argues that since Eisenstein cinema has sought to make the image readable and not just visible, to make an image such that when it is seen it is read, and that this culminates in Godard's image "lisible pour son compte". ${ }^{30}$ The image has become legible for itself through the irrational cut having superseded the rational cut. The irrational cut separates sound from image, purifies the image of any speech to which it would rationally be joined, allowing both visual image and sound image to attain their 'own' limit. It is a separateness common to both, yet the only way this commonality can be acknowledged is through the irrational cut. ${ }^{31}$ The irrational cut thus has a double effect, it separates speech from what is seen, and at the same time it joins speech in its separateness, or what Deleuze prefers to call its purity, to that which it is separate from. The more this double operation is carried out on the visual 
image, the more readable it becomes. Deleuze calls the resulting images, images to be read as much as to be seen, 'lectosigns' - a lectosign is the site of a junction, the junction between disjunction and conjunction. ${ }^{32}$ In English there is not lecto but lector, reader, from legere, to read. It has two senses: ecclesiastic, one whose duty it is to read the lesson; and academic, a reader or lecturer in a university. Or in other words, following the irreducible sense attaching to this word we arrive at a teaching delivered through reading. A lectosign then would be a sign which lectures through the reading of it. A sign which when it is seen reads to the viewer, a sign which is not so much read when seen as seen reading to the viewer.

Images in which what is said bears no rational relation to what is seen are images which have been purified of rational correspondence. Such images are autonomous, cut off from the world, non-totalisable. ${ }^{33}$ Images which have been disjoined in this way, and in their disjointedness conjoined, are masters over their own framing, they are images which no longer have an outside, they are images "comme un pouvoir de se retourner sur ellesmêmes". ${ }^{34}$ No longer governed by text, no longer ordered by the already written scripts of the discourses of literature or politics or privilege, they are images of things 'before the word' ascribed by pre-existing discourses. And yet they are all the more readable for that. What Deleuze means by reading is a retournement of the image, an act where the empty screen is converted into a full one. ${ }^{35}$ The question is whether Deleuze sees the reversal of the image as itself reversible, that is whether it can go both ways, where what is said can bring into question what is seen, and where what is seen can bring into question what is said, or whether the reversal is one way, what is said bringing into question what is seen. Or in other words, to what extent is Godard's visible world 'beyond or before words' a reversible play between what is seen and said, or simply a one-way reversal where because what is seen is what cannot be heard, the image becomes raised to the power of the unspeakable. If the reversal is indeed reversible, it will lead to the reversal of the rational towards the irrational, and the irrational back towards the rational. Not back to a rational left unchanged as a result of the reversal, but a rational at play with what it is opposed to rather than at war with it, and where play is not reduced to a benign non-oppositionality but elevated to a questioning of where and when the distinction between the two falls, a questioning where the answer cannot be governed by the rational without reinforcing the very distinction being put into question, therefore negating the questioning force of the play. Such a reversibility would not leave film under the condition of the irrational as if the irrational were opposed to the rational, it would instead elevate it to the status of a thinking adequate to the play between the rational and the irrational. We will see shortly that this cannot be a dialectical process.

So long as the relation between sound and image is governed by the rational, the potentiality of images will always be negated in favour of 
establishing and fixing a one-way dependency, where either what is seen determines what is sayable, or what is said determines what is visible; and in order to avoid this Deleuze divides the image into a visual purified of the word and an audible purified of the seen, the first stage of a two-stage process before the two are re-linked irrationally. But is not this first stage distillation itself a rational operation? How else to separate the said in the seen and the seen in the said, other than by a rationality of identification and purification? Deleuze speaks of the way the films of Marguerite Duras or Jean-Marie Straub and Danièle Huillet purify the speech act of the authority of the text. ${ }^{36}$ But at the same time they reveal a certain resistance of the text to itself. Godard does the same thing by showing words on the screen. By repeating as an image a word spoken Godard displaces text from the constativity of the speech act. In making text visible he displaces the word from the intentionality of the speech act, revealing a materiality in excess of and resistant to its subjection or reduction to intentional relations between characters in a dialogue or between character and the referents of their utterances. By reading words and sentences from the page he frees text up from the fixity of the book and its subjugation by argument or by narrative logic. In both cases a resistance internal to the text itself is performed. But it is not a final word, it is a temporal displacement, one which gives the viewer time to think.

There is in Godard, for Deleuze, a "primat trés spécial" of the word over the image, in that the word can act as a category which orders the image and through which images must pass. ${ }^{37}$ Categories are not derived from each other, they are connected by 'and', where 'and' can stand for any and every relation. As a category the written word acts as the passage between series, and can induce mutations between them. Categories problematise the image, and thereby "introduisent la réflexion dans l'image même." It is this reflection which we are calling the general readability of the image in Godard. To distinguish between the written word as a category and the visual image as the series ordered by the category ought not to lead to the implication that the written word is not an important visual image in Godard. Indeed, and unlike the other examples Deleuze gives of the categories in Godard comprising his 'table of categories', for instance things, acts, and people, we are arguing here that the written word has been no more fully and comprehensively introduced into cinema than by Godard, to the extent that we might say that it is his invention, that it is his Godard's category. The written word is the privileged visual image in Godard, in that its privilege is double, first in the sense that as an image the written word can act as a category through which other images must pass; and second because the image of the written word is Godard's specific contribution to the categorial images structuring the history of cinema.

Deleuze avers that it would be wrong to think that modern cinema is similar to silent cinema in its re-introduction of text in the form of intertitles 
and other scriptural elements. In silent cinema intertitles were there to be read, whereas images in which other scriptural elements are present were there to be seen in the same way other non-scriptural types of images were there to be seen. Today, however, "c'est l'image visuelle qui doit être lue tout entière", and images of intertitles are but one layer of scripturality, or the passage from one layer to another. ${ }^{38}$ There is no longer one element which makes the image readable today; rather the image is readable as such, all of it, and that is because the speech act has become autonomous from the image. Intertitles and other images of text are but the pointillées, as Deleuze puts it, the dots, of a generalised readability. This readability is 'stratigraphic', or archaeological, where the dots are evidence of something deeper. Deleuze characterises the stratigraphic image in exactly the same way he does the lectosign, "lue en même temps que vue". ${ }^{39}$ The choice of stratigraphy to name the kind of writing that makes the image in general readable is significant. It implies layers spread out or thrown down, a coating where the graphy is tectonic or of strata. According to the Oxford English Dictionary, stratigraphy is almost the only example of this rare hybrid between descriptive science and style or process of writing that has obtained general currency. With it Deleuze names what he calls "une nouvelle Analytique de l'image". ${ }^{40}$ Godard's great pedagogical contribution to this new analytic of the image is to have shown how the screen, the pictorial surface, is constituted by the word, is textualised from the start, how the underside of film is coated with text. There is always word and image emerging into what is seen, and always word and image coming down from over what is heard. Godard's images are stagings of the play between the text under and the text above the seen and the heard, between what in the seen is seen and heard from below and above, and what in the heard is seen and heard from above and below.

Contra Deleuze, there is no purification involved, because there never was a pure visual image or a pure speech act. If in silent cinema the intertitle was used to reinforce the naturalness of what was shown or the causal sense of the actions represented, then it was not simply the imposition of text on a naturally pre-given, pre-verbal image, it was as well the acknowledgement that the natural and the represented are already verbalised, already given by the word. In its use of the intertitle to join the image to a certain naturalness and to fix it in a given order of causal relations, silent cinema revealed the power of the word to disjoin the image from its condition of naturalness and to interfere with the causal relations between given actions. Throughout Godard's work and his numerous interviews there is an appeal to the 'before the name', to a showing of things that would present the object before the name that would fix it in the order of language, before the name comes to stand for the thing itself, before the name acts as if it has let the thing come into being, and at that moment negating the thing. ${ }^{41}$ It might seem from such utterances and his appeal to a showing of things 'before the name' that Godard simply laments the introduction of text. To the contrary his films 
reveal the extent to which the relation is reversible, and how text too can return words and things to states before the name, and can disorder relations between words and things such that the naming authority of the image is brought into question no less than that of the name, where the word is no longer ordered by the power that images have to naturalise, no longer governed by a taxonomical privilege given by the authority of illustration, no longer subject to the weight of revelation disbursed by the true icon. In short, image and text are held apart in Godard's films, at just that moment before text disappears into the image, before it disappears into what makes it visible as Giorgio Agamben puts it. ${ }^{42}$ The written image is the making explicit of this moment, of 'the power of stoppage' that is cinema's gift.

We see it especially in the TV series Six fois deux, in which Godard and Anne-Marie Miéville construct a series of daily lessons, the primary teaching of which is Seeing is not what you think it is. Each of the six episodes of Six fois deux is divided in two, and the division is essentially along the lines of image and text. The first part is the lesson of things, images of objects, the second a language lesson, text as object: two parts of the same lesson. Both teach the same lesson, and that lesson is that if you are going to see there cannot be one without the other, but that the two must be held apart in order to see their unity. It is not possible to see things, to see things anew and as if for the first time, without the word given by text. As the second episode 'Leçons de choses' puts it, what can be seen appears in the interval between where text and image, image and text, become the here and the elsewhere. And it is that interval which is legible, it is a legibility which holds text and image apart, and at the same time it is the space in or the surface on which can stand the viewer, the viewer in turn becoming the point where the two, image and text, become indiscernible. The play of the separateness and non-separateness of image and text is staged on the surface film, on Godard's opaque screen, where the written image stands as the making explicit of this moment, but that play cannot be understood or sensed without the two, image and text, becoming indiscernible on the body of the viewer.

We can understand why, then, Jacques Fieschi speaks of a "certain pedagogical frustration" to be heard in the "white voice' of Godard's narration appearing to create its citations rather than borrow them. ${ }^{43}$ This 'pedagogical frustration' is part of the film being stopped, its pause, it is the moment of study. It is the lesson of APPRENDRE A VOIR PAS A LIRE (Ici et ailleurs). It is akin to how Agamben characterises the experience of he who studies, in that to study is to be stopped and stunned. The st-root of studium is the shock of impact: 'those who study are in the situation of people who have received a shock and are stupefied by what has struck them'. ${ }^{44}$ This is not the stammer or the stutter learnt off by heart by the disciple, the 'Deleuzian', it is dumb pause before the beginning again, the relearning how 
to speak, it is Godard rubbing things together such that their finality is worn through to expose the need to look again, read again.

3.

Jacques Rancière too accepts the basic premise that Godard's films are about learning to see and to read; not just about learning to read phrases but "lire avec elles". ${ }^{45}$ For instance La Chinoise is about learning to 'read with' the phrases from Mao's Little Red Book. Rancière sees this learning to 'read with' as an Althusserian dialectic of the 'deux en un', such that "quand le mot «fait voir», il ne se laisse plus entendre. Et quand l'image fait entendre, elle ne se laisse plus voir". ${ }^{46}$ Rancière is at one with Godard's own understanding of his films when he says of the crossover of word and image "Les mots font image. Ils font voir." What Godard wants, according to Rancière, is to "interrompre le défilement, la substitution incessante des mots qui font voir et des images qui parlent, imposant la croyance", to disassociate word from image, to break apart the unity of an image in which words play a determinate role in what we see, and images do likewise for what we hear. ${ }^{47}$ To disassociate word from image is to make of the relation between the two a lesson. If Godard actually shows a lesson, together with all its apparatuses including the blackboard, then he does so not just to challenge the authority of 'big words' and the regimes of discourses already said, already written, but to pose the question whether the attainment of authenticity in the use of words isn't in fact just like being before the blackboard, for the word must be made visible in order for the viewer to see what it is saying. ${ }^{48}$ About La Chinoise it appears that Rancière is in agreement with Deleuze and Daney, that Godard does not take sides and refuses to make a decision for one discourse over another, simply setting discourses in tension with each other through their visualisation. ${ }^{49}$ But elsewhere Rancière seems to contradict this, when for instance he argues that Godard's unbinding of images in Histoire(s) du cinéma, rather than giving them independence "overbinds them in another ideological plot" ${ }^{50}$ If the seeming contradiction can be accounted for it will be because Godard's practice of separating and rejoining image from text, image to text denies us the authority by which we might decide whether he does choose or does not, because his films will include instances of choice or non-choice and then these instances reconfigured once more through their text being repeated and displaced in the reading if it.

Rancière is also no different from Deleuze in saying that another way Godard achieves disassociation which would lead us to 'believe' is to return the word to the body. Returning the word to the body is to make of the word a gesture. To play out the word as a gesture on the body is another way of making the word visible, allowing it in turn to be heard for what it is. Indeed, in having the word played out as a gesture is to allow discourses of one sort to look like discourses of another, for instance the words and gestures of political discourse can be made to look like the utterances and 
attitudes of a love affair. But Rancière critiques Godard's practice of disassociation for how it leads to an infinitisation of the possible ways in which the disassociated image can be re-linked with other images, in particular in Histoire(s) du cinéma. In his project of wresting the cinematic image from its subservience to the script, Godard has a tendency to make of the filmic image an icon, by separating it from the narrative arrangement from which it gained its original sense. For Rancière we do not remember an image in a Hitchcock film for example, say the glass of milk in Suspicion, because of its pictorial value but because of how it plays a part in the narrative of the film and how its value as an image is given it precisely by the narrative in which it is fixed and by which it is ordered. Thus the criticism is that Godard 'dissociates the indissociable' ${ }^{51}$ But to dissociate the indissociable is what Rancière himself does when he separates what is 'pictorial' in the image in Hitchcock from its place in the narrative. One way of enhancing narrative is to draw out the image pictorially, to separate it from its straightforward narrative placement, by the cinematic means of framing and rhythm for instance, which momentarily arrests the narrative logic only then to impress it on the surface of the screen more deeply and to propel the narrative more urgently. This is precisely what Hitchcock does. For Godard to borrow an image worked by Hitchcock in this way is not simply for Godard to draw an element out of narrative and separate it pictorially, it is to see firstly that Hitchcock himself does this in order to enhance the narrative; and second it is to realise that the creation of such images in Hitchcock is itself the work of montage, montage being the art of stopping the film, to give us time to think about it. For Godard to take an image from Hitchcock is to have seen the image not just in terms of its content, but as a form under the condition of montage, where its developed pictorial nature is not at odds with the narrative arrangement it is drawn from, but on the contrary is what allows it to link ever more strongly with other elements in the narrative. The condition of montage is not something that happens to an image from without, it is the image having been separated from itself through cinematic means.

But for Rancière if Godard disjoins an image from itself, or as he puts it transforms the image as image through a process of soustraction from the film's continuum, it is not to create a disjunction in which to intervene. Indeed, he argues that Godard's work has undergone an about-turn since the militant films of the 1960s/70s. Where once Godard may have fragmented an image or a narrative in the service of revealing hitherto unseen, suppressed or unacknowledged interests, of learning how to see, how to read with, where a narrative of revolution can be made to sound like that of a love affair, in the later work, particularly in Histoire(s) du cinéma, the same process is used to release images for their part in a film "whose aesthetic name is mystery and whose political name is History", 52 the mystery of co-belonging, the history a 'reserve historicity' of infinite connection..$^{53}$ The process is the same in both cases, but it is what the images 
are freed for and re-linked for that has changed. Where before Godard could be said to be unbinding and re-binding images in the name of dialectic, now he does so in the name of symbolism. ${ }^{54}$ In both cases it involves doing two things, displacing the image from text, from its subservience to the script, and creating a space in which all elements can be shown to belong equally. ${ }^{55}$ This space in which the image is no longer coupled to the text and in which all elements belong equally Rancière names a 'sensorium originaire'. It implies a co-presence not just of elements but of the discourses and images which shape them and give them sense, in which text has no more or less authority than image. It is a realm in which "toute chose parle deux fois", in its presence as the thing in itself, 'before the name' in Godard's sense, unencumbered by the ascription of word by dominant pre-existing discourses, and in its possible connections with every other element, where what something speaks is given it by its being mixed and associated with those other elements co-present. ${ }^{56}$

Rancière characterises this as a dialectic, between non-manipulation and manipulation, between non-manipulated unmediated pure presence and manipulated meaning through association given by montage ${ }^{57}$ It is nothing less than the tension at the heart of Romanticism, the sheer sensibility of the non-manipulable versus the absolute freedom of creation. ${ }^{58}$ Godard's method and his own expressed intentions may appear to favour the first of these two processes, but Rancière argues that he is obliged to utilise the second method to enhance the first, for pure presence can only be achieved through manipulation. Images are elevated to their ownmost presence by the same gesture that renders them polyvalent. ${ }^{59}$ Purity is made possible by the very power which allows an image to be linked to another, the power of montage. But montage is not possible without the co-presence of the word in the same frame as the image. Thus there is no such thing as an image of pure presence disassociated from the text of signification or discourse. Godard's method is not dialectical; or rather if it is dialectical then it is also not, and more fundamentally not, and it is the written image which makes this explicit. We are arguing that the written image is outside the opposition between image and text. If this is so then it is that which a dialectic would necessarily have to dialecticise. If Rancière were right and Godard's is a dialectic then Godard would be showing the written image in order to dialecticise it. But what is being shown here is that the written image is a supplement to the dialectic in the sense given this term by Jacques Derrida, the supplement to the dialectic is that which does not allow itself to be dialecticised. $^{60}$ In doing so it reveals a non-oppositional difference, a difference that does not oppose the image-text opposition yet nonetheless stands outside it. But in making the dialectic impossible such an image would re-launch the dialectic. The written image, being outside the imagetext opposition, is precisely that which a dialectics of image and text would necessarily have to dialecticise if the method is one of dialectics. Thus we can say that Godard's method is outside dialectics but not opposed to it. It is 
in Derrida's terms an attempt at a dialecticity which is not dialectical. The written image in Godard resists the dialectical without opposing it. For this reason we cannot say that Godard's method is one of opposition. The written image is like a third term, as if it wanted to touch the edges of both image and text, to participate on one side and the other, but giving itself up to neither, arresting the image before what is seen disappears into discourse, or before what is said disappears into the image. But this does not make his method anti-dialectical, for that too would be dialectical in opposing it. Rather, it is neither dialectical nor non-dialectical, a non-dialectical dialectics, where text the greatest risk of death becomes the saving power of cinema, if that is it can be shown as image, written image.

If text is as necessary for the rescue of an image from its subservience to script as it is for the script to exert its dominance over image, then there is no essential difference between modern cinema and representational cinema. And in this regard it is interesting to note that Rancière does specify a difference, not within cinema, but between cinema and what it therefore is not, between cinema and literature, and he locates it in the fact that cinema is essentially a matter of showing: "The difference is that cinema is deprived of the subtracting power of literature, namely, the ability not to show what it 'shows'. Cinema still shows what it shows. As a consequence, it must enforce its capacity to withdraw the obviousness of what it shows." ${ }^{61}$ Here then we are returned to an essential difference between cinema and literature on the level of the image. If cinema cannot not show it is because it is first and foremost image. If literature can not show, if it can subtract, then it is because literature is text. Cinema can subtract an image from its order in a narrative and from its subservience to script, but it cannot subtract the image from its being an image, it cannot subtract from the image the showing of the image, all it can do is lessen the obviousness of what is shown by the image but which is nonetheless and always shown. But this is to reinstate the distinction between an image being essentially without text, and text being essentially without image. Rancière is mistaken to think that cinema does not have the power not to show. On the contrary, the power at its disposal can do more than lessen the obviousness of what it shows, it can withhold what it shows. It is a twofold power, it consists in the fact that cinema is both image and text, and in its being able to show text. Words have the power to make us see and not see, where what the image shows is itself a consequence of the way it is passed through text.

Rancière affords little attention to the multiple images produced by Godard which are written images. His notion of the 'phrase-image', introduced in 2003, also does not take account of the written image as a separate image, or an image which might make more explicit the relation of what is anyway implicit in the relation of text to image in images. ${ }^{62}$ When he discusses the relation of image to text in La Chinoise for instance he does so referring to the word as it is discoursed by characters or played out as 
gesture on their bodies, and not to the images of text inscribed in and across the frame. There is no explicit mention of the written image, no consideration given to the possibility that in being made into a written image the phrase is visibilised. At best the phrase "institue un quasi-visible qui ne vient jamais pourtant à la clarté de l'image." ${ }^{63}$ But if on the other hand when we see a word we cannot hear it, what exactly is being shown? If the word shown in the image of a written word is made unreadable in its being shown, it is not simply the lessening of the word's 'obviousness', it is the subtraction of what is shown. If images are made to pass through written images made unreadable in the word being shown then what is subtracted from being shown is the power of other discursive formations and scripts already written that may otherwise govern what those images show, thereby are those images re-shown, not detached from the word but in new relations with it. Rancière's cross-over [chassé-croisé] of image and text is overly determined by a conception of language as essentially the spoken word. To name it 'cross-over' may seek to reduce the oppositionality, but Rancière finds it difficult not to privilege the understanding over the sensible. His 'quasi-visible', the image that never attains the clarity of an image, entailing and being entailed by the quasi-audible that an image is, is heard before it is seen, is audible before it is written. There may be two quasis, each entailing the other, and each "dure seulement le temps qu'il faut pour faire le travail de l'autre et enchaîner son pouvoir de disparition sur celui de l'autre"; ${ }^{64}$ but when we consider the written image we find that an image can become invisible or less visible not by becoming audible but by becoming visible, visible in the form of legible.

Deleuze speaks of how perception is an act of subtraction; we never really see the fullness of images because our perception is overly determined by the images we have already seen. We see only what interests us in an image, and take away from it what is not of interest, where 'interest' is a function of other images we have already seen. Thus the more we see the less we perceive. ${ }^{65}$ But when an image is passed through text, what is of interest in the image is less determined by our experience of other images and more by how it gives itself to be read. Here 'fullness' is not the image's ability to 'store' other images, and nor is it pace Deleuze a restored plenitude such that our perception 'equals' the image, as if the image is "giving up everything it has". Rather, its fullness is its enhanced possibilities for reading and for linking to other images and other discourses which would otherwise be subtracted by other images. But resistance to the subtraction exerted by another image is itself subtraction, it is the power of language in the form of written image to take away from what is shown by the image 'in itself'. 
4.

Not only do images have to pass through the word in Godard, but the word is made to pass through the image. If Godard cannot read Heidegger he is nonetheless offered paths by Heidegger's texts that "pass through the image", separating the image from itself, distancing the viewer from within the image, displacing the viewer without removing him. Only through this play of separation and non-separation does the image become visible. ${ }^{66}$ To read a text is to learn from it how to speak it - and speaking a text distances the reader from what the text says. In inscribing the word as a path written through the image Godard is saying that we do not simply know texts in understanding them or by reading them, but in fragmenting them, dispersing them into images, passing them though images, and undergoing them by way of the image, making them differently legible. If he puts into question what we think we know about a text, or what we presuppose about its relation to the image, he does so by confronting it not with an argument but with an image. If that form be the written image then the text is confronted with itself as an image. Likewise, in reading out loud he gives a text not as something to be understood in the form of an argument or a narrative, but as something to be heard and to be encountered as what can be heard in the word. The text is re-directed on to the image, the image is allowed to confront what can be heard. Making text something to be encountered rather than something 'in the service of' runs counter to Deleuze's Artaud-critique of recognition and the uprightness of language. For text to be confronted it must be recognised, recognised in the sense of looked at in the face. So Godard needs to retain its literal uprightness, its stance, in order that its face be looked at and its uprightness in both a metaphorical and metaphysical sense confronted and challenged.

Godard shows text not in order to reiterate its uprightness but to challenge it, to put into question its upright stance, or in other words its moral authority over the image, the order of dependency it exerts over the image - but he can only do this by confronting it. He seeks ways of giving the text as something to be encountered, sensed. And for these reasons its uprightness must be renewed, for only then will text be allowed to question its subservience to the image and be questioned about it. It is a making sensible something about the text that would be otherwise invisible or inaudible were it simply to be understood as subservient to what is said by the image. In Godard the word does not stand for the thing it names and does not stand in for it. Rather, Godard sensibilises the word of the thing, stands it up to be materially encountered. This is not to return the word to the body as Deleuze argues. It is to displace the body to a site where it can encounter the struggle between image and text. The body becomes the point of indiscernibility between image and text. It is the point at which the sense of reading is divided by the sensibility of what is written, where sense is divided by sense. This is to question the authority of the script, it is to put 
into question the privilege of the understanding over sensibility. But it is not simply to invert the hierarchy, instating the one, sensibility (or in Deleuze's terms the affect, the rational), over the other, understanding (the irrational).

Godard repeats words. If a word is repeated it is not because it is uniform or to make it uniform. It is repeated in order to hear what is said in the word. It is repeated in order to make it possible again, to renew it in its possibility. This is not a question of polyvalence eliciting or revealing multiple meaning, but of what is brought to the word in saying it in the form of an image. When Godard utters and shows 'et' again and again in Ici et ailleurs it is not the same thing that is said each time, on the contrary 'and' is different each time, and the identicalness of sound and spelling cover over both what is the same in that word, namely its potential, and what is different in that word, a word which can stand for any and every relation. If the word were shown because of some presumed uniformity with how it is read then this showing would be nothing but representational. Godard's written images are representational, but not just representational. They do not take as given in advance the equivalence of reading the word and showing the word; rather, their representationality consists in the fact that representation is as much a matter of text as it is visual. Godard's is neither the purification of image and text (Deleuze) nor the dialectic between them (Rancière). He may seem to oppose the pictorial to the textual, but his sense of the pictorial is deepened when he introduces text into its frame, and the surface of the frame must already have depth in order that text be showable there. What Godard seeks is what all artists seek, the moment where the holding apart of image and text and their indiscernibility meet. It is the point when there can be no question that image is in text and text is in image, where our only responsibility is to inquire into what the relation between the two might be in this text or in that image.

1 Jean-Luc Godard, "Struggle on two fronts: A conversation," with Jacques Bontemps, Jean-Louis Comolli, Michel Delahaye, Jean Narboni, Cahiers du cinéma, trans. D. C. D., Film Quarterly, Vol. 21, No. 2. (Winter 1968-Winter 1969): 31.

2 Jean-Luc Godard, "La curiosité du sujet," entretien avec Dominique Paini et Guy Scarpetta, Art Press, numéro spécial Godard (février 1985) : 5.

3 Jean-Luc Godard, “Hitchcock est mort” (1980), in Jean-Luc Godard par Jean-Luc Godard, tome 1: 1950-1984, ed. Alain Bergala. (Paris: Cahiers du cinéma, 1985), 416. 
${ }^{4}$ Jean-Luc Godard, in Jean-Luc Godard \& Youssef Ishaghpour, Archéologie du cinéma et mémoire du siècle. Dialogue. (Tours: Farrago, 2000), 81.

${ }^{5}$ Jean-Luc Godard, "The future(s) of film," interview with Emmanuel Burdeau and Charles Tesson, in Jean-Luc Godard, The Future(s) of Film: Three Interviews 2000-01, trans. John O'Toole. (Bern: Verlag Gachnang \& Springer AG, 2002), 19-20.

6 Jean-Luc Godard, "Blinde Liebe - Gespräch mit Jean-Luc Godard" (2001), Alexander Kluge, Der Angriff der Gegenwart auf die übrige Zeit und Vermischte Nachrichten, Edition Filmmuseum DVD 27 (München: Filmmuseum \& Goethe-Institut, 2007).

${ }^{7}$ Godard, Archéologie du cinéma, 81.

${ }^{8}$ Godard, "Hitchcock est mort," 416.

${ }^{9}$ Godard, Archéologie du cinema, 40.

${ }^{10}$ Jean-Luc Godard, “Le droit d'auteur? Un auteur n'a que des devoirs," entretien avec Jean-Marc Lalanne, Les Inrockuptibles, $18 \quad 2010$ (http://blogs.lesinrocks.com/cannes2010/2010/05/18/le-droit-dauteur-un-auteur-na-que-desdevoirs-jean-luc-godard/).

${ }^{11}$ I discuss Godard's frequent citation of Wittgenstein on the relation of seeing to touch, eye to hand, in "The condition of film as philosophy; or, How can a film ask a question?," Film and Philosophy, vol. 10 (2006): 135-50.

12 Jean-Luc Godard, "Quand j'ai commencé à faire des films, j'avais zéro an," Libération, 15 et 16 (mai 2004): 49.

${ }^{13}$ Godard, "Struggle on two fronts," 25.

${ }^{14}$ Robert Bresson, Notes on Cinematography, trans. Jonathan Griffin. (New York: Urizen Books, 1977), 67.

${ }^{15}$ Godard, Archéologie du cinema, 18.

${ }^{16}$ Godard, “La curiosité du sujet," 11.

${ }^{17}$ Godard, “Quand j'ai commencé à faire des films," 49.

${ }^{18}$ Godard, “La curiosité du sujet," 11.

${ }^{19}$ Jean-Luc Godard, Cinéthique, Nㅜ 5 (septembre-octobre 1969).

${ }^{20}$ Jean-Luc Godard, “What is to be done?," trans. Mo Teitelbaum, Afterimage, no. 1 April 1970).

${ }^{21}$ Gilles Deleuze, Cinéma 1, L'image mouvement. (Paris: Les Éditions de Minuit, 1983), 24.

${ }^{22}$ Gilles Deleuze, "Trois questions sur Six fois deux", in Cahiers du cinéma, N 271 (novembre 1976): 10.

${ }^{23}$ Serge Daney, “Le Therrorisé (Pégagogie godardienne)," in La Rampe: Cahier critique 1970-1982. (Paris: Cahiers du cinéma/Gallimard, 1983), 80.

${ }^{24}$ Deleuze, Cinéma 2, 224.

${ }^{25}$ Gilles Deleuze, Différence et repetition. (Paris: Presses universitaires de France, 1968), 192. 
${ }^{26}$ Gilles Deleuze \& Félix Guattari, Qu'est-ce que la philosophie? (Paris: Les Éditions de Minuit, 1991), 52. I analyse this shift in Deleuze's work, or what we might call a tension internal to it, in "Deleuze and the image of thought," forthcoming in Philosophy Today.

27 Gilles Deleuze, “Sur L'image-mouvement” (1983), Pourparlers. (Paris: Les Éditions de Minuit, 1990), 75.

${ }^{28}$ Gilles Deleuze, “Lettre à Serge Daney: Optimisme, pessimisme et voyage” (1986), Pourparlers. (Paris: Les Éditions de Minuit, 1990), 100.

${ }^{29}$ Gilles Deleuze, Cinéma 2, L'image temps. (Paris: Les Éditions de Minuit, 1985), section three of "Components of the image," especially 319-28.

${ }^{30}$ Deleuze, Cinéma 2, 322.

${ }^{31}$ Deleuze, Cinéma 2, 364.

32 See the 'Glossary' in the English translation of Cinéma 2 not present in the original French. Gilles Deleuze, Cinema 2, The Time-Image, trans. Hugh Tomlinson and Robert Galeta. (London: The Athlone Press, 1989), 335.

${ }^{33}$ Deleuze, Cinéma 2, 329.

${ }^{34}$ Deleuze, Cinéma 2, 347.

${ }^{35}$ Deleuze, Cinéma 2, 319.

${ }^{36}$ Deleuze, Cinéma 2, 330 and 337.

${ }^{37}$ Deleuze, Cinéma 2, 242.

${ }^{38}$ Deleuze, Cinéma 2, 320.

${ }^{39}$ Deleuze, Cinéma 2, 319.

${ }^{40}$ Deleuze, Cinéma 2, 319.

${ }^{41}$ Godard, “La curiosité du sujet," 5.

42 Giorgio Agamben, “Difference and repetition: On Guy Debord's films”, trans. Brian Holmes, in Tanya Leighton (ed.), Art and the Moving Image: A Critical Reader. (London: Tate Publishing/Afterall, 2008), 333.

43 Jacques Fieschi, "Mots en images", Cinématographe: la revue de l'actualité cinématographique, $N^{\circ} 21$ (octobre-novembre 1976): 11.

${ }^{44}$ Giorgio Agamben, Idea of Prose, trans. Michael Sullivan and Sam Whitsitt. (New York: State University of New York Press, 1995), 64.

45 Jacques Rancière, “Le rouge de La Chinoise: politique de Godard," La fable cinématographique. (Paris: Éditions du Seuil, 2001), 189 [my emphasis].

${ }^{46}$ Rancière, “Le rouge,” 189.

${ }^{47}$ Rancière, “Le rouge,” 190.

${ }^{48}$ Rancière, “Le rouge,” 195.

${ }^{49}$ Rancière, “Le rouge,” 194. 
50 Jacques Rancière, “Godard, Hitchcock, and the cinematic image," in Michael Temple, James S. Williams, and Michael Witt (eds.), For Ever Godard. (London: Black Dog Publishing, 2004), 226.

51 Jacques Rancière, “Une fable sans morale: Godard, le cinéma, les histories," La fable cinématographique. (Paris: Éditions du Seuil, 2001), 219.

${ }^{52}$ Rancière, “Godard, Hitchcock,” 226.

${ }^{53}$ Rancière, “Une fable sans morale," 226.

${ }^{54}$ Rancière, “Godard, Hitchcock,” 231.

${ }^{55}$ Rancière, “Une fable sans morale," 222.

${ }^{56}$ Rancière, “Une fable sans morale," 225.

${ }^{57}$ Jacques Rancière, Le destin des images. (Paris: La Fabrique éditions, 2003), $66 \mathrm{f}$.

58 Jacques Rancière, "Cinematographic image, democracy, and the 'splendor of the insignificant,"” interview with Solange Guénoun, trans. Alyson Waters, in Sites, The Journal of $20^{\text {th }}$. century/Contemporary French Studies revue d'études françaises, Vol. 4, Issue 2 (Fall 2000): 255.

${ }^{59}$ Rancière, “Une fable sans morale,” 235-6.

60 Jacques Derrida, "I have a taste for the secret," in Jacques Derrida and Maurizio Ferraris, A Taste for the Secret, trans. Giacomo Donis. (Cambridge: Polity Press, 2001), 32,

${ }^{61}$ Rancière, “Godard, Hitchcock,” 221.

${ }^{62}$ Rancière, Le destin des images, 56.

${ }^{63}$ Rancière, “Le rouge,” 189.

${ }^{64}$ Rancière, “Le rouge,” 190.

${ }^{65}$ Deleuze, “Trois questions," 10.

${ }^{66}$ Godard, "Quand j'ai commencé à faire des films," 49. 
